Among the commercial computer participants are Fritz, GeniUs, HiarCS, M_Chess Pro, ThE King, Chessica, Rebel, The King Tasc-Base, Kallisto, Virtual Chess, Nimzo, Isichess, W_Chess

Four programs will play via a remote distance connection CilKCHESS, HiTECH, ZugZWANG and DARK THOUGHT

Moreover, a large group of amateur entries will participate We mention GANDALF, ANT, CD 20 , Now, Diep, Dappet, Cheiron, Shredder, Ferret, Arthur, Capture, Bionic, Goldbar, Max Chess Aegon '97, HeKTOR, SCHACH 3 0, RAJA, XXXX II, DiOGENES

We would like to attend you on the participation of CLEVER \& SMART It is the successor of DREIHIRN [see also Althofer's contribution elsewhere in this issue - Ed] For DREIHIRN or DOUBLE-FRITZ with Boss a human being decided on the move by selecting a proposed move In CLEVER \& SMART the decision will be made by a program, in this case by the World Microcomputer Chess Champion Program SHREDDER

Moreover, some commercially-available chess programs will also participate, such as MEPHISTO GENIUS 68030/60 MHz, R30 22 and R40 25

There is no entry fee for spectators The game scores will be accessible via Internet Moreover, some games in progress can be followed on Internet

\title{
THE INTERNATIONAL COLLOQUIUM BOARD GAMES IN ACADEMIA
}

\author{
Leiden, The Netherlands \\ April 6-10, 1997
}

$$
\text { A de Voogt' }
$$

Baarn, The Netherlands

The third International Colloquium on Board Games in Academia will take place in Leiden, The Netherlands, from April 6 to 10, 1997 Scholars using board games in research and scholars interested in research on board games are invited Lectures on board games will deal with distinct topics mostly seen from an interdisciplinary perspectıve

It is the third colloquium on board games, after the initial colloquium at the British Museum in London in 1990, and the second colloquium at the Leiden University in 1995 Board-games research is 1eceiving increasing attention as shown by the first day of the 1997 colloquium programme containıng a group of entirely new researchers in the field

\section{Programme:}

April 7 (dedicated to board-games research and language)

A van der Stoep

Board games, language and Miss Bourion

P Mebben

Th Depaulis

L Verbeeck

Rithmomachia, the Philosopher's Game - a mediaeval battle of numbers

B Rothohler Inca Dice and Board Games

Bul a Maya Board Game

Mehen, God of the Board Games

April 8 (dedicated to mancala-games research and theoretical issues)

Dr V Eagle

Classification of mancala

Dr U Schadler

Mancala in Roman Asia Minor?

IGM Y Averbakh

About the transformation of race games into war games

A Foum Simultaneous blind bao demonstration

1 Da Costalaan 1, 3743 HT Baarn, The Netherlands 
Apul 9 (dedicated to museum and archeological research)

C Goodfellow Historical Children's Board Games 1772-1850

Dr I Finkel A Classification of Graffit Games of the Roman Empire (by R C Bell)

$\mathrm{N}$ Ivanova Russian Chess Museum chess pieces

I Riddlei Taefl and the Anglo-Saxons

April 10 (contrastıng people and machınes)

Dr Matsubara

Differences between Shogı and Western Chess from a computational view

Dr Finkel

Life and work of Faulkner

The programme is subject to change For hotel reservation or registration forms, please contact

Alexander J de Voogt

Da Costalaan 1

3743 HT Baan

The Netherlands

Tel +31 355430697

\section{THE 1996 ICCA BEST-ANNOTATION AWARD}

$D$ Levy $^{1}$ and T A Marsland ${ }^{2}$

London, England / Edmonton, Canada

In ICCA Jouınal, Vol 15, No 4, pp 235-236 we announced the ICCA Best-Annotation Awald for the first tıme We received two entries for this first Award, viz THE CHESSMASTER 4000 TURBo and M_ChESS Pro 35 A jury nominated by the Board of ICCA declared THE CHESSMASTER 4000 TURBO the winner of the 1993 ICCA Best-Annotation Award (see Vol 17, No 2, pp 106-108)

The 1994 ICCA Best-Annotation Award has been presented to Jeft Mallett's Innovatıon Program, Sherrills Ford, North Carolına (see Vol 18, No 1, pp 38-43) The 1995 ICCA Best-Annotation Award has been given to FriTz 40 especially to its analysis component by Matthias Wullenweber) (see Vol 19, No 2, pp 135-136)

Unfortunately, no entries were received by December 31, 1996 for the 1996 ICCA Best-Annotation Award We understand that there was a prospective entry of some merit, but the owners of the program had forgotten the deadlıne for entıles

We hope that 1997 will produce a significant improvement in both the quality and quantity of entries in ielation to the past years The ICCA believes that a good annotation program will make a significant contribution to the chess world

\section{Call for Entries for the 1997 ICCA Best-Annotation Award}

Annotatıon programs should be submitted on disk to David Levy and/or Tony Marsland, complete with full operatıng instructions in Englısh, to anıve not later than December 31st, 1997 The software on the disk must run under a standard system, such as DOS, MacOS, Windows or Unix

Background information for the previous competitions can be found in previous issues of the Journal and on the ICCA home page URL http //www cs unımaas nl/1cca/

\footnotetext{
89, Constantıne Road, London NW3 2LP, England Ema1l DavidL@1ntrsrch demon co uk

2 University of Alberta, Computıng Science Department, Edmonton, Alberta, Canada T6G 2H1

Email Tony Marsland@ualberta ca
} 